Information for citation:

Sumachev, A. V. (2021) Criminal Law Conditions for Conducting a Scientific Experiment on a Person. European and Asian Law Review. 4 (1), 69-75. DOI: 10.34076/27821668_2021_4_1_69.

UDC 343.3/.7

BISAC LAW 026000LAW

DOI: 10.34076/27821668_2021_4_1_69

Research article

\title{
CRIMINAL LAW CONDITIONS FOR CONDUCTING A SCIENTIFIC EXPERIMENT ON A PERSON
}

\author{
ALEXEY V. SUMACHEV \\ Ugra State University \\ ORCID ID: 0000-0002-1133-9574
}

The problem of causing harm to a person's health during an experiment (including for medical purposes), and the issue of the person's consent for conducting the experiment by third parties has long been in the focus of legal scholars. Recent developments in the Russian criminal legislation have intensified research in this sphere. There is no doubt that in modern society we need to find an adequate balance between the achievements of science and the basic values of persons, and, first of all, their life and health. In this regard, it is necessary to elaborate a clear definition of legitimate conditions for conducting a scientific experiment on a person under criminal law. Relying on the analysis, deduction and induction of scientific views regarding the conduct of a scientific experiment on persons and their consent to it, the author of the article has formulated universal conditions necessary and sufficient for such an experiment.

Key words: scientific experiment, object of experiment, legitimate conditions for conducting a scientific experiment, harm to health, consent of a person, criminality

\section{Introduction}

The problem of scientific and technological progress stands out among other problems in the context of modernization of society with issues of legal support for this process to be resolved. A particular question inter alia is the question of the legal basis for conducting a scientific experiment on a person. In the conditions of active interstate integration processes it seems necessary to develop universal rules for conducting a scientific experiment on a person, and namely to elaborate on the issue of legitimacy for conducting a scientific experiment on a person under criminal law.

\section{Materials and methods}

In the process of research the author has relied on general scientific (analysis, deduction, induction) and specific scientific (legal interpretation) methods.

\section{Results}

The results of the author's research are presented in the final part of the work - conclusions.

\section{Discussion}

At the very outset, let us note that a scientific experiment on persons is one of the forms of inflicting harm to their health by third parties, but with the consent of the person. At the same time, it is worth 
pointing out that the issue of consent and its impact on causing harm to health by third parties has had a long history. For example, in the beginning of the twentieth century, I. J. Fojnickij noted that '... injuries inflicted with the consent of a victim are not criminal, because there is a possibility to refuse from the benefit of bodily integrity' (Fojnickij, 1907: 67). Some time later, regarding this problem, N. S. Tagantsev wrote: 'Consent destroys liability in all those cases where the main focus is not on physical suffering, but on moral, on violence against the person, and violation of personal integrity: it is impossible to provide for criminal liability of a person who has pulled someone's ears or hit someone on the back, if he did so at the request or with the consent of the victim. As a result, there is more serious harm inflicted to the body: injuries and health problems' (Tagantsev, 1994: 184). Thus, depending on the moral or physical character of the act, N. S. Tagantsev has determined the criteria for distinguishing between criminal and non-criminal encroachment on bodily integrity. In case of attacks on bodily integrity for the purpose of causing moral suffering, consent destroys liability for the act. If the purpose is different, like causing physical suffering, the act should be recognized as criminal, though N. S. Tagantsev himself does not recognize this thesis absolute, referring to such arguments as actions of a doctor in the blood transfusion process, conducting scientific experiments, etc. (Tagantsev, 1994: 184).

Soviet scholars also had a sort of ambiguous approach to the solution of this problem, primarily, because there might be different degrees of gravity of bodily injuries (harm to health). In particular, I. I. Slutsky spoke about the criminality of causing grievous bodily harm (Belyaev \& Shargorodsky, 1968: 370); E. Ya. Nemirovsky (Nemirovsky, 1925: 369) and A. A. Zhizhilenko (Zhizhilenko, 1927: 35) - about the absence of criminality when causing harm with consent; A. A. Piontkovsky (Piontkovsky, 1961: 473), P. A. Dubovets (Dubovets, 1964: 19), N. I. Zagorodnikov (Zagorodnikov, 1969: 24) linked criminality (non-criminality) with the purpose of inflicting grievous bodily harm - either for social benefit or harm. A relatively similar position is taken by L. L. Kruglikov. In particular, he writes: 'The consent of a person to cause harm to their health does not exclude criminal liability of the harm causer, with some exceptions (lawful medical intervention; participation in sports competitions with physical contact; participation in an experiment)' (Kruglikov, 1999: 53).

In their turn, A. I. Santalov (Belyaev \& Shargorodsky, 1968), T. V. Kondrashova (Kovalev, Kozachenko, \& Neznamova, et al., 1997), A. V. Ivashchenko (Martsev, 1998) consider that only cases of causing serious or moderate harm to persons' health with their consent shall be viewed as criminal acts. They justify their position by the institute of private prosecution, according to which causing minor harm to health (minor bodily harm) is punishable only based on the complaint of the victim. So, A. V. Ivashchenko notes that '... as for acts that cause physical (bodily) harm to a person, it can be caused in the amount not exceeding that established for crimes, the prosecution of which can be terminated on the initiative of the victim'(Martsev, 1998). Practically a similar position is expressed by Yu. M. Tkachevsky: 'In case of deprivation of life and causing any, except minor, harm to health, the consent of the victim has no legal significance' (Kuznetsova \& Tiazhkova, 2002). However, he immediately notes: 'The attribution of causing minor harm to health and insults to the cases of private prosecution does not mean that victims give their consent to such actions, but rather they refuse from possible criminal prosecution of their abuser for one reason or another' (Kuznetsova \& Tiazhkova, 2002).

Thus, the infliction of serious or moderate harm to health, even with the consent of a person, must be recognized (and is recognized) as criminal. Regarding non-criminality of causing minor harm to health with the consent of a person, we do share the opinion of A. I. Santalov, T. V. Kondrashova, A. V. Ivashchenko, Yu. M. Tkachevsky, but we should make a few remarks.

The last two positions seem fairer to us for a number of reasons. It is very difficult to find grounds to justify non-criminality of causing even minor harm to persons' health with their consent. In this regard, it is reasonable to shift the focus from the material grounds of such justification to the formal aspects provided for by criminal legislation. In particular, we can assume that if the legislator has traditionally linked and still links the initiation of criminal proceedings for causing minor harm with the expressly stated consent of a person, then this rule can also be applied to exclude criminality of an act causing such harm with the consent of a person. But again, we would like to emphasize the correct statement by Yu. M. Tkachevsky that the nature of causing harm with consent is not equal to the legal nature of initiating criminal proceedings. In the former case, the act is not criminal at the time of its commission; in the latter 
case, the crime is actually committed, and the victim's will is manifested only when deciding whether to initiate criminal proceedings (or refuse to do so).

However, individual acts of causing harm to health with the consent of a person may exclude criminality of the act. Such circumstances occur, for example, in cases of conducting a scientific experiment on a person.

The problem of causing harm to a person's health during an experiment (including for medical purposes) has long been in the focus of legal scholars (Greenberg, 1963; Greenberg, 1992; Krasikov, 1976; Kurlandsky \& Khan-Magomedov, 1972; Malein, 1975; Sivokon', 1968). Recent introduction of Article 41 'Reasonable Risk' in the current Criminal Code of the Russian Federation ${ }^{1}$ (hereinafter referred to as the RF CC) has intensified research in this sphere.

It should be noted that legal theory and practice distinguish between cases of conducting an experiment on a sick person and on a healthy person (Samarokov, 1994: 65-66; Krasikov, 1976: 99). At the same time, among the main prerequisites for legitimacy of conducting a medical experiment on a sick person, A. N. Krasikov identifies the following: 1) performing the experiment in the interests of a patient and 2) the consent of the patient or his/her legal representative to the experiment. And here he concludes that '...that the patient's consent only to the testing of an innovative method or medicine makes medical intervention illegal' (Krasikov, 1976: 99-100).

We should emphasize that in accordance with the Fundamentals of Legislation of the Russian Federation on Protection of Citizens' Health ${ }^{2}$ (hereinafter referred to as the Fundamentals), modern legal and medical practice permits the use of methods of diagnosis and treatment and the use of medicines - that are not allowed for use yet, but are under consideration in the prescribed manner - in the interests of treating the patient only after obtaining his/her voluntary written consent (Article 43 (2) of the Fundamentals). At the same time, methods of diagnosis and treatment and medicines - that are not allowed for use, but are under consideration in the prescribed manner - can be used for the treatment of persons under the age of 15 only if there is a direct threat to their lives and with the written consent of their legal representatives (Article 43 (3) of the Fundamentals). The procedure for the use of these methods of diagnosis and treatment, medicines, immunobiological preparations and disinfectants, including those used abroad, shall be established by the Ministry of Health of the Russian Federation or other authorized bodies (Article 43 (4) of the Fundamentals).

Regarding legitimate conditions for conducting a scientific experiment on a healthy person, A. N. Krasikov identifies the following:

1) the experiment shall be scientifically grounded,

2) the consent shall be expressed by the person himself/ herself,

3) possible success shall be proportionate to possible risk,

4) there shall be socially useful motives and goals (Krasikov, 1976: 100).

V. I. Samarokov, in his turn, points out the following:

a) a socially useful goal (to preserve and reinforce health, or save lives of other people),

b) compliance of risky actions with modern achievements in medical science and practice,

c) the exceptional nature of risky actions (the inability to achieve a socially useful goal in any other way),

d) taking all measures to prevent possible harm,

e) a truly free and clearly expressed consent of a person (Samarokov, 1994: 65).

M. N. Maleina has elaborated on legitimate conditions for conducting an experiment (including for medical purposes) from the standpoint of modern doctrine and legislation (Maleina, 2001). Analyzing Article 43 of the Fundamentals, she underlines the necessity to:

1) provide full preliminary information concerning the upcoming experiment (full information concerning the goals, methods, duration, expected result, side effects and other possible risk),

2) receive free written consent of the person who is the object of research (with the purpose to eliminate hidden forms of coercion, it is banned to conduct biomedical research involving persons arrested or detained, serving sentences in penitentiary facilities or prisoners under administrative arrest as objects of such research),

\footnotetext{
${ }^{1}$ Collection of Legislation of the Russian Federation (1996) No. 25. Art. 2954.

${ }^{2}$ Collection of Legislation of the Russian Federation (2011). No. 48. Art. 6724.
} 
3) conduct a preliminary laboratory experiment (the experiment shall be scientifically grounded and confirmed by well-developed methodology (with an issued protocol or any other document), evidence recorded by medical devices, film- or photographic equipment, or any other equipment, or by the testimony of witnesses or observers),

4) conduct an experiment in a state or municipal health care institution (or under the control of these institutions, when it comes to conducting research in space, under the ground, under water, etc.) (Maleina, 2001: 81)

M. N. Maleina does not consider conditions for legitimacy of conducting such an experiment specified in Article 43 of the Fundaments to be sufficiently complete, therefore she notes: 'The legislation needs to be supplemented with a number of other conditions. First, while conducting an experiment, the interests of a participant must prevail over the interests of science and society. The experiment shall be stopped if there is a risk of death or irreversible deterioration of the health of a volunteer or a possible violation of their other rights and interests. Secondly, it is necessary to resolve the issue of remuneration and compensation for the harm caused to a participant of the experiment. Remuneration and compensation for damage caused are not contrary to the moral principles of society and shall be compensated by the organization responsible for the preparation and conduct of the research. Thirdly, the written consent of a volunteer is not sufficient to formalize a relationship with a health care institution, since it only protects the interests of such an institution. It would be reasonable to approve a mandatory written form of a contract for conducting biomedical research with all the conditions specified' (Maleina, 2001: 82).

At the same time, despite a rather exhaustive list and description of conditions for legitimacy of conducting such an experiment proposed by M. N. Maleina, the list cannot be still considered sufficient. This is probably due to a certain extent to its civil law regulation, while the assessment of the experiment under criminal law has some special features.

Criteria for assessing legitimacy of conducting an experiment directly follow, first of all, from criminal law (Article 41 of the RF CC), as well as from other intersectoral legislation (for example, Article 43 of the Fundamentals). First, let us focus on those of them that are exclusively regulated by criminal law or which are of a mixed (intersectoral) nature.

It should be noted that experimental actions fall within the scope of criminal law regulation only when they result in criminally significant harm: in this case, either inflicting death or harm to health. Minor harm to health intentionally inflicted with the consent of a participant in the course of the experiment excludes criminality of the act. Causing death or harm to the health of an object (person) of the experiment by negligence (provided all other conditions of the experiment are met) also excludes criminal liability of the head of the experiment. This rule follows from the contents of Article 41 (3) of the RF CC. Thus, under criminal law, one of the prerequisites for legitimacy of conducting an experiment is the consent of the person - the object of the experiment - only to cause minor harm to his/her health during the experiment. Cases of inflicting any harm negligently are investigated under the rules of reasonably risky actions (Article 41 of the RF CC).

The second condition for conducting a scientific experiment is contained in Article 41 (1) of the RF CC - causing harm to achieve a socially useful goal. This criterion is of a universal nature, including its regulation under criminal law.

Another condition for legitimacy of a scientific experiment identified, in particular, by V. I. Samarokov, cannot be compared with the criteria of risky actions, and, namely, because a socially useful goal cannot be achieved by actions (inaction) that are not related to risk (Article 41 (2) of the RF CC). The fact is that unlike reasonable risks, the goals of a scientific experiment (and even for medical purposes) can vary from the development of completely new methods, projects and models to the modernization of existing ones. For example, in preventing influenza it is possible to rely either on 'grandfather's methods' (the use of sudorific medicine like honey, raspberry jam, steaming in the bath, etc.) or on pre-vaccination. In other words, we are speaking about alternatives of actions (methods) of prevention. Thus, in general, in order to achieve a socially useful goal as a reasonable risk, one of the conditions for legitimacy of conducting a scientific experiment is the exceptional nature of such actions (i.e. the inability to achieve this goal by any other means). A scientific experiment, as indicated, involves not only the development of a completely new idea, but also the modernization of the old one. In the latter case, we are talking about the most effective means of achieving a socially useful goal, which can be achieved by the old 'grandfather's 


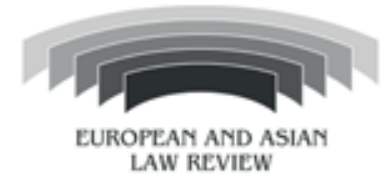

Vol 4. Is. 1

methods'. It is the nature of achieving the final socially useful goal that makes it necessary to distinguish between conditions of legitimacy related to a reasonable risk and the ones related to a scientific experiment. Thus, 'the impossibility of achieving a socially useful goal in any other way' as a condition for legitimacy of a reasonable risk is a category that complies with the relevant condition for legitimacy of a scientific experiment, but is not identical to it. As a condition for legitimacy of conducting a scientific experiment, it copies to a certain extent the second of the above conditions, and namely, the achievement of a socially useful goal; therefore, it is not worth identifying this criterion as an independent condition.

Further, we should say a few words about another condition for legitimacy of a reasonable risk, under which a person allowing risks has still taken sufficient measures to prevent harm to the interests protected by criminal law (Article 41 (2) of the RF CC). Similarly, V. I. Samarokov formulates this condition as: 'A medical worker at risk undertakes all possible measures to prevent harm to the health or threat to the life of ...a person who has been the object of a medical experiment' (Samarokov, 1994: 65). In our opinion, the formulation of the above mentioned condition for legitimacy of conducting a scientific experiment offered by the legislation (Article 41 of the RF CC) and by V. I. Samarokov is not entirely successful, because it has a rather vague nature. Indeed, the assessment of sufficiency (insufficiency) of the experimenters' actions to prevent harm may depend on a number of both objective and subjective factors. On the one hand, we can speak, for example, about insufficient scientific and practical knowledge at this stage of development of certain laws of the functioning of human organs and tissues, the effects of drugs, the paradoxical response of the body, etc. (Samarokov, 1994: 66). On the other hand, we can speak about a lack of appropriate skills, as well as strong-willed and intellectual qualities of the one conducting the experiment. There is no doubt that practical proposals (recommendations) concerning the conditions for legitimacy must meet the requirements of specificity and applicability. In this connection, it is probably worth turning to one of the conditions for conducting a scientific experiment, which A. N. Krasikov (Krasikov, 1976) and M. N. Maleina (Maleina, 2001), as well as Article 43 of the Fundamentals focus on: the scientifically grounded nature of legitimacy of an experiment (confirmed by a previously conducted laboratory experiment). At the same time, fully sharing the opinion of M. N. Maleina stated above, we should emphasize that the scientifically grounded nature of an experiment can and shall be confirmed by:

1) the developed methodology for conducting an experiment, duly confirmed by the relevant documents (protocols, etc.),

2) positive results of the study, recorded by devices and other means of visual tracking, as well as by witnesses or observers of the laboratory experiment,

3) appropriate specialization and professionalism of those conducting the experiment.

Thus, the third universal (mixed) and mandatory condition for legitimacy of causing criminally significant harm during a scientific experiment is the scientifically grounded nature of an experiment.

The fourth condition for legitimacy of conducting a scientific experiment is the consent of a person to cause harm to his/her health. Again, it is necessary to identify a certain condition stated by the legislator (Article 43 of the Fundamentals) and M. N. Maleina, namely, the condition of providing complete preliminary information on the upcoming experiment: on goals, methods, duration, expected result, side effects and other possible risks (Maleina, 2001: 82). If speak about the conditions for legitimacy of conducting a scientific (medical) experiment, there is no doubt that it is necessary to provide this kind of information. At the same time, identifying the necessary and sufficient conditions for legitimacy of conducting a scientific experiment and, in particular, the consent of a person as one of such conditions, we should rely on the presumption that the object (person) of an experiment shall be aware of the goals, methods, duration, expected result, side effects and other facts concerning the experiment. Thus, submission of truthful and exhaustive information should be defined as a special-sector condition for legitimacy of conducting particular types of scientific experiments. In a whole set of conditions for legitimacy of conducting a scientific experiment, the category of 'consent' implies that a person is fully informed of the experiment.

We should focus on one more feature that characterizes the conditions for legitimacy of conducting a scientific experiment - conducting such an experiment under the control of the state, because of a possibility to cause criminally significant harm to human health (to the object of the experiment). Of course, all issues related to the infliction of such harm are subject to assessment by the state. In this regard, the opinion of M. N. Maleina, which is also reflected in Article 43 of the Fundamentals, that 
scientific experiments associated with causing harm to human health shall be carried out either in state or municipal institutions or under their direct control (Maleina, 2001: 81).

However, while identifying general (including criminally significant) conditions for legitimacy of conducting a scientific experiment, it is not necessary to consider other special conditions, such as:

ensuring the priority of the interests of an individual over the interests of science and society while conducting the experiment (this principle seems to follow from Article 2 of the Constitution of the Russian Federation and does not require duplication in special areas of activity),

remuneration and compensation for the harm caused to the participant of the experiment (this issue is of a purely special nature, because by the nature of their professional activity certain categories of citizens are obliged to risk their health),

necessity to introduce a mandatory written form of the contract for conducting an experiment and some others (it seems that, depending on the nature of an experiment, the written form of expressing consent to a specific type of experiment can be expressed in various documents, including in the form of a contract, though the form itself does not seem important) (Maleina, 2001: 82).

\section{Conclusion}

Thus, among the universal conditions necessary and sufficient to speak about the legitimacy of conducting a scientific experiment on a person, one should distinguish:

1) a possibility of causing serious or moderate harm to a person's health, but not death,

2) causing harm when it is necessary to achieve a socially useful goal,

3) the experiment must be scientifically grounded,

4) the consent of a person to participate in the experiment as an object (the consent to be harmed),

5) conducting an experiment under the control of the state.

Sectoral legislation may provide for special conditions setting the limits for conducting a scientific experiment on a person.

\section{References}

Belyaev, N. A. \& Shargorodsky, M. D. (eds.) (1968) Kurs sovetskogo ugolovnogo prava. Chast' obshchaia [Course of Soviet Criminal Law. General Part]. Saint Petersburg, Leningrad Univ. Publ. House. (in Russian).

Dubovets, P. A. (1964) Otvetstvennost' za telesnye povrezhdeniia po sovetskomu ugolovnoти pravu [Liability for Bodily Injuries under Soviet Criminal Law]. Moscow, Yurid. Lit. (in Russian).

Fojnickij, I. J. (1907) Kurs ugolovnogo prava. Chast' osobennaia: Posiagatel'stva lichnye $i$ imushchestvennye [A Course of Criminal Law. Special Part: Personal and Property Encroachments]. $5^{\text {th }}$ ed. Saint Petersburg, Type. M. M. Stasiulevich. (in Russian).

Grinberg, M. S. (1963) Problema proizvodstvennogo riska $v$ ugolovnom prave [The Problem of Production Risk in Criminal Law]. Moscow, Gosiurizdat. (in Russian).

Grinberg, M. S. (1992) Tekhnicheskie prestupleniia [Technical Crimes]. Novosibirsk, Novosibirsk Univ. Publ. House. (in Russian).

Kovalev, M. I. Kozachenko, I. Ya. \& Neznamova, Z. A. et al. (1997) Ugolovnoe pravo. Obshchaia chast': Uchebnik dlia vuzov [Criminal Law. General Part: a Coursebook for Higher Schools]. Moscow, INFRA-M: Norma. (in Russian).

Krasikov, A. N. (1976) Sushchnost' i znachenie soglasiia poterpevshego v sovetskom ugolovnom prave [The Essence and Meaning of the Consent of the Victim in the Soviet Criminal Law]]. Saratov, Saratov Univ. Publ. House. (in Russian).

Kruglikov, L. L. (ed.) (1999) Ugolovnoe pravo Rossii: Chast' osobennaia: Uchebnik dlia vuzov [Criminal Law of Russia: Special Part: a Coursebook for Higher Schools]. Moscow, BEK. (in Russian).

Kurlyandsky, V. \& Khan-Magomedov, D. (1972) Estestvennye nauki i ugolovnoe pravo [Natural Sciences and Criminal Law]. Sots. zakonnost. (2), 26-29. (in Russian).

Kuznetsova, N. F. \& Tiazhkova. I. M. (eds.) (2002) Kurs ugolovnogo prava. Tom 1. Obshchaia chast': Uchenie o prestuplenii [A Course of Criminal Law. Vol. 1. General Part: a Study of Crime]. Moscow, Zertsalo. (in Russian). 
Malein, N. S. (1975) Pravo na meditsinskij eksperiment [The Right to a Medical Experiment]. The Soviet State and Law. (11), 35-41. (in Russian).

Maleina, N. M. (2001) Lichnye neimushchestvennye prava grazhdan: poniiatie, osushchestvlenie, zashchita [Moral Rights of Citizens: Concept, Implementation, Protection]. 2nd ed. Moscow, MZ Press. (in Russian).

Martsev, A. I. (1998) Ugolovnoe pravo Rossijskoj Federatsii (Obshchaia chast'): Uchebnik [Criminal Law of the Russian Federation (General part): a Coursebook]. Omsk: Law Institute of the Ministry of Internal Affairs of Russia. (in Russian).

Nemirovsky, E. Ya. (1925) Sovetskoe ugolovnoe pravo: posobie k izucheniiu nauki ugolovnogo prava $i$ dejstvuiushchego Ugolovnogo kodeksa SSSR: ch. obshchaia i osobennaiia [Soviet Criminal Law: a Guide to the Study of the Science of Criminal Law and the Current Criminal Code of the USSR: General and Special Parts]. Odessa. (in Russian).

Piontkovsky, A. A. (1961) Uchenie o prestuplenii po sovetskomu ugolovnomu pravu. Kurs sovetskogo ugolovnogo prava [The Doctrine of Crime under Soviet Criminal Law. The Course of Soviet Criminal Law ]. General and Special Parts. Moscow, Gosyurizdat. (in Russian).

Samarokov, V. I. (1994) Ugolovno-pravovaia otsenka meditsinskogo riska. Sovremennye tendetsii razvitiia ugolovnoj politiki i ugolovnogo zakonodatel'stva [Criminal Law Assessment of Medical Risk. Modern Trends in the Development of Criminal Policy and Criminal Legislation]. Moscow, Institute of State and Law of the Russian Academy of Sciences. (in Russian).

Sivokon', P. E. (1968) Metodologicheskie problemy estestvennonauchnogo eksperimenta [Methodological Problems of a Natural Science Experiment]. Moscow, Moscow Univ. Publ. House. (in Russian).

Tagantsev, N. S. (1994) Russkoe ugulovnoe pravo. Lektsii: Chast' obshchaia [Russian Criminal Law. Lectures: General Part]. Vol. 1. Moscow, Nauka. (in Russian).

Zagorodnikov, N. I. (1969) Prestupleniia protiv zdorov'a [Crimes against Health]. Moscow, Yurid. lit. (in Russian).

Zhizhilenko, A. A. (1927) Prestupleniia protiv lichnosti [Crimes against the Person]. Moscow, Saint Petersburg, State Publ. House. (in Russian).

\section{Information about the author}

Alexey V. Sumachev - Doctor of Juridical Sciences, Professor, Professor of the Criminal Law and Criminal Procedure Department, Ugra State University, Khanty-Mansiysk, Russia (4 Chekhov str., apt. 16, Khanty-Mansiysk, Khanty-Mansi Autonomous Okrug-Ugra, 628012, Russia, e-mail: alekssumachev@mail.ru).

(c) A. V. Sumachev, 2021

Date of Paper Receipt: June 15, 2021

Date of Paper Approval: July 1, 2021

Date of Paper Acceptance for Publishing: July 26, 2021 